\title{
IDENTIFIKASI KADAR AMILOSA BERAS PANDANWANGI DARI TUJUH KECAMATAN DI KABUPATEN CIANJUR
}

\author{
Oleh: \\ Melissa Syamsiah**) \\ Maesy Masliah*) \\ Email : melissasyamsiah@gmail.com
}

\begin{abstract}
Abstrak
Salah satu komoditi padi yang menghasilkan beras dengan kualitas unggul di wilayah Kabupaten Cianjur adalah beras Pandanwangi. Beras yang asli Pandanwangi hanya dapat ditanam di tujuh kecamatan di Kabupaten Cianjur yang telah sesuai dengan persyaratan indikasi geografis untuk penanaman padi Pandanwangi. Ciri khas nasi Pandanwangi adalah kepulenannya. Kepulenan nasi dipengaruhi oleh kadar amilosa beras sebelum dimasak. Untuk itu dilakukan penelitian yang bertujuan mengidentifikasi kadar amilosa beras Pandanwangi dari tujuh lokasi kecamatan yang berbeda. Penelitian dilakukan di Laboratorium Ilmu Dasar Fakultas Sains Terapan Universitas Suryakancana dan di Laboratorium Farmasi Universitas Al Ghifari Bandung pada bulan Februari sampai Maret 2019. Penelitian menggunakan Rancangan Acak Kelompok (RAK) dengan 7 perlakuan dan 3 kelompok. Masing-masing perlakuan yaitu beras Pandanwangi dari lokasi A (Cibeber), B (Campaka), C (Warungkondang), D (Cianjur), E (Gekbrong), F (Cugenang) dan G (Mande). Hasil penelitian menunjukkan dari ke tujuh lokasi tanam yang berbeda menghasilkan kadar amilosa pada taraf sedang sesuai dengan karakteristik beras Pandanwangi, kecuali kecamatan Mande dengan kadar amilosa beras Pandanwangi yang tinggi.
\end{abstract}

Kata Kunci: Kadar Amilosa, Beras Pandanwangi, Tujuh Kecamatan

\begin{abstract}
One of the rice commodities that produce superior quality rice in the Cianjur Regency is Pandanwangi rice. Pandanwangi original rice can only be planted in seven sub-districts in Cianjur Regency which are in accordance with the geographical indication requirements for planting Pandanwangi rice. The hallmark of Pandanwangi rice is its tenency. The extinction of rice is influenced by the amylose content of rice before cooking. For this reason, research was conducted aimed at identifying Pandanwangi rice amylose content from seven different sub-district locations. The study was conducted at the Laboratory of Basic Sciences at the Faculty of Applied Sciences at Suryakancana University and at the Pharmacy Laboratory of Al Gbifari University in Bandung from February to March 2019. The study used a Randomized Block Design (RBD) with 7 treatments and 3 groups. Each treatment is Pandanwangi rice from locations $A$ (Cibeber), $B$ (Campaka), C (Warungkondang), D (Cianjur), E (Gekbrong), F (Cugenang) and G (Mande). The results of the study showed that from seven different planting locations, amylose content was at a moderate level in accordance with the characteristics of Pandanwangi rice, except Mande sub-district with high amylose content of Pandanwangi rice.
\end{abstract}

Keywords: Amilosa Content, Pandanwangi Rice, Seven Districts

*) Alumni Fakultas Sains Terapan UNSUR

**) Dosen Fakultas Sains Terapan UNSUR 


\section{PENDAHULUAN}

Padi Pandanwangi (Oryza sativa $\mathrm{L}$. var. Aromatica) adalah padi yang termasuk varietas local unggulan kota Cianjur yang sudah terkenal sampai ke luar negeri. Beras Pandanwangi memiliki harga jual yang relatif lebih tinggi dibanding varietas yang lain karena memiliki beberapa keunggulan, diantaranya kepulenannya, aroma daunpandan yang membuat rasa menjadi lebih enak (Asih dan Syamsiah, 2019).

Salah satu komoditas tanaman padi yang memiliki beras yang kualitas unggul adalah padi varietas Pandanwangi. Beras Pandanwangi dikembangkan secara turun temurun oleh masyarakat Kabupaten Cianjur. Daerah sentra penghasil padi Pandanwangi di Kabupaten Cianjur hanya terdapat di tujuh Kecamatan saja, yaitu Cianjur, Warungkondang, Cilaku, Cibeber, Gekbrong, Cugenang dan Campaka (MP3C, 2015).

Masyarakat Indonesia sebagian besar mengkonsumsi beras sebagai kebutuhan pokok makanannya. Beras mengandung nilai gizi nutrisi yang cukup tinggi. Kandungan karbohidrat dalam beras cukup tinggi, dalam $100 \mathrm{~g}$ beras diketahui mengandung 78\% karbohidrat, jenis karbohidrat yang terkandung dalam beras diantaranya pati atau amilum. Pati terdiri dari dua fraksi yaitu amilosa dan amilopektin. Salah satu perbedaan kedua fraksi tersebut adalah stukturnya, diketahui bahwa amilosa mempunyai struktur lurus dan amilopektin mempunyai rantai cabang (Winarno, 2002 dalam Boediono, 2012). Jenis beras yang mengandung amilosa rendah dan amilopektin tinggi adalah beras ketan (waxy rice) yang sifatnya lebih lengket setelah ditanak dibandingkan beras yang mengandung amilosa tinggi dan amilopektin rendah (beras non ketan). Beras tropis diketahui mengandung amilosa lebih dari $20 \%$. Pengelompokkan beras berdasarkan kandungan amilosa adalah sebagai berikut: kandungan amilosa tinggi
$(>25 \%)$, sedang $(20-24 \%)$, dan rendah $(<20 \%)$ (Luna et al., 2015).

Kadar amilosa menentukan kualitas rasa, kepulenan dan sifat fisik lainnya. Beras yang memiliki kadar amilosa tinggi mempunyai sifat nasi yang keras/pera, sedangkan beras yang memiliki kadar amilosa rendah memiliki sifat nasi yang pulen. Selain itu diketahui bahwa beras yang memiliki kandungan amilosa tinggi memiliki Indeks Glikemik (IG) rendah, hal ini disebabkan beras dengan kadar amilosa tinggi sifatnya lambat dicerna karena struktur amilosa yang berantai lurus konsentrasinya lebih tinggi sehingga menjadi lebih kuat ikatannya dan sulit tergelatinisasi, pada akhirnya akan lambat menaikkan kadar gula darah serta memiliki IG yang rendah (Lestari, et al., 2018).

\section{METODE PENELITIAN}

\section{Waktu dan Tempat}

Penelitian ini dilaksanakan pada bulan Februari - Maret tahun 2019 bertempat di Laboratorium Ilmu Dasar Fakultas Sains Terapan Universitas Suryakancana dan Laboratorium Farmasi Universitas Alghifari Bandung.

\section{Alat dan Bahan}

Alat yang digunakan dalam penelitian yaitu pinset, kaca pembesar, lampu duduk, cawan petri, spatula, cawan porselen, penjepit cawan, oven, timbangan analitik, labu ukur, labu Erlenmeyer, pipet, spektrofotometer dan lain-lain.

Bahan yang digunakan dalam penelitian yaitu sampel beras padi varietas Pandanwangi dari tujuh kecamatan yang berlokasi di Cibeber, Campaka, Warungkondang, Cianjur, Gekbrong, Cugenang, dan Mande. Bahan lain untuk pengujian yaitu larutan indikator metilen blue (ml), $\mathrm{HCl} 0,02 \mathrm{~N}$, aquades, amilosa (mg), larutan etanol 95\% (ml), larutan $\mathrm{NaOH}(\mathrm{ml})$, larutan iod dan lain-lain. 


\section{Analisis Kadar Amilosa}

Penentuan kadar amilosa dengan menggunakan metode spektrofotometri (AOAC, 2006) dilakukan 2 tahap, yakni:

a. Tahap pembuatan kurva standar, dengan cara:

1) Amilosa murni ditambahkan sebanyak $100 \mathrm{mg}$ ke dalam labu takar $100 \mathrm{ml}$.

2) Ditambahkan $1 \mathrm{ml}$ etanol $95 \%$ dan $9 \mathrm{ml} \mathrm{NaOH} 1 \mathrm{~N}$.

3) Labu dipanaskan di dalam penanggas air selama 10 menit kemudian didinginkan selama 1 jam.

4) Kemudian ditambahkan aquades sampai volume $100 \mathrm{ml}$.

5) Larutan tersebut dipipet masingmasing 0,$25 ; 0,5 ; 0,75 ; 1,5 ; 1,25 ; 1,5$; 1,75 dan 2,0

6) Lalu pada larutan tersebut ditambahkan $2 \mathrm{ml} \mathrm{I}_{2}$ dan asam asetat 0,$5 ; 1,0 ; 1,5 ; 2,0 ; 2,5 ; 3,0 ; 3,5$ dan $4,0 \mathrm{ml}$.

7) Ditambahkan aquades ke dalam masing-masing labu takar tersebut sampai volume $100 \mathrm{ml}$.

8) Kemudian absorbannya diukur pada panjang gelombang $620 \mathrm{~nm}$.

b. Tahap penetapan sampel, dengan cara:

1) Sampel beras ditambahkan sebanyak $100 \mathrm{mg}$ ke dalam labu takar $100 \mathrm{ml}$.

2) Ditambahkan $1 \mathrm{ml}$ etanol $95 \%$ dan $9 \mathrm{ml} \mathrm{NaOH} 1 \mathrm{~N}$.

3) Labu dipanaskan di dalam penanggas air selama 10 menit kemudian didinginkan selama 1 jam.

4) Kemudian ditambahkan aquades sampai volume $100 \mathrm{ml}$.

5) Larutan sampel dipipet $5 \mathrm{ml}$ dan ditambahkan $2 \mathrm{ml} \mathrm{I}_{2}$ dan $1 \mathrm{ml}$ asam asetat.

6) Ditambahkan aquades ke dalam labu takar tersebut sampai volume 100 $\mathrm{ml}$.

7) Kemudian absorbannya diukur pada panjang gelombang $620 \mathrm{~nm}$.
Kadar amilosa sampel dihitung

berdasarkan rumus:

Absorban $1 \mathrm{ppm}=\frac{\frac{\mathrm{I}}{0.25}+\frac{\mathrm{II}}{0,50}+\cdots+\frac{\mathrm{VII}}{2,0}}{8}$

Perhitungan dilanjutkan dengan rumus:

Kadar amilosa $(\%)=\frac{\text { Abs sampel }}{\text { Abs } 1 \mathrm{ppm}} \times 20 \times \frac{100}{100-\text { Kadar air }}$

\section{Rancangan Percobaan}

Penelitian menggunakan

Rancangan Acak Kelompok (RAK) non faktorial, Dengan perlakuan adalah 6 kecamatan asal budidaya beras Pandanwangi dan kontrol sebagai pembanding dengan 3 kelompok. Yang menjadi perlakuan :

$A=$ Kecamatan Cibeber

$\mathrm{B}=$ Kecamatan Campaka

$\mathrm{C}=$ Kecamatan Warungkondang

$\mathrm{D}=$ Kecamatan Cianjur

$\mathrm{E}=$ Kecamatan Gekbrong

$\mathrm{F}=$ Kecamatan Cugenang

$G=$ Kecamatan Mande sebagai kontrol

\section{Teknik Analisis Data}

Teknik analisis data untuk memperoleh data kuantitatif yakni dengan uji Analisis Sidik Ragam atau ANOVA (Analysis of Variance), kemudian untuk perlakuan yang berpengaruh akan uji lanjut Tukey dengan taraf 5\%.

\section{HASIL DAN PEMBAHASAN}

\section{Data Beras Pandanwangi di Tujuh Lokasi Kecamatan}

Penelitian menggunakan beras Pandanwangi yang berasal dari lokasi kecamatan yang berbeda, yaitu Kecamatan Cibeber, Kecamatan Campaka, Kecamatan Warungkondang, Kecamatan Cianjur, Kecamatan Gekbrong, Kecamatan Cugenang dan Kecamatan Mande. Beras Pandanwangi yang digunakan dalam penelitian diambil dari waktu musim panen yang hampir bersamaan, yaitu pada bulan Juni 2018. Data tersebut dapat dilihat pada tabel 1. 
Tabel 1. Data musim tanam, tanggal panen dan tanggal beras Pandanwangi masuk ke laboratorium setiap lokasi Kecamatan.

\begin{tabular}{clccc}
\hline No & \multicolumn{1}{c}{ Lokasi } & Musim Tanam & Tanggal Panen & $\begin{array}{c}\text { Tanggal Masuk ke } \\
\text { Laboratorium }\end{array}$ \\
\hline 1 & Cibeber & 2018 & 21 Juni 2018 & 18 Februari 2019 \\
2 & Campaka & 2018 & 22 Juni 2018 & 18 Februari 2019 \\
3 & Warungkondang & 2018 & 25 Juni 2018 & 18 Februari 2019 \\
4 & Cianjur & 2018 & 27 Juni 2018 & 18 Februari 2019 \\
5 & Gekbrong & 2018 & 25 Juni 2018 & 18 Februari 2019 \\
6 & Cugenang & 2018 & 14 Juni 2018 & 18 Februari 2019 \\
7 & Mande & 2018 & 08 Juni 2018 & 18 Februari 2019 \\
\hline
\end{tabular}

Observasi mengenai data beras perlu dilakukan sebelum pengujian kadar amilosa dari tujuh lokasi tanam Pandanwangi. Hal ini disebabkan pengujian yang menggunakan beras dengan waktu panen berbeda, apalagi dalam jangka waktu yang lama akan mempengaruhi kualitas fisik dan kimia beras. Selain itu diketahui faktor yang mempengaruhi kualitas beras, antara lain:

(1) varietas, (2) penanganan pascapanen, (3) teknik budidaya, dan (4) kondisi lingkungan (Setyono et al., 2006).

\section{Pengujian Kadar Amilosa beras Pandanwangi}

Kadar amilosa adalah rantai lurus yang terdiri dari molekul-molekul glukosa yang merupakan pati dengan struktur tidak bercabang (Jane dan Chen, 1992 dalam Boediono, 2012). Kadar amilosa menunjukkan kandungan amilosa yang tersimpan dalam sampel, dalam hal ini kadar amilosa dalam beras. Data kadar amilosa beras Pandanwangi dari tujuh Kecamatan yang menjadi objek penelitian terdapat dalam Gambar 1. Hasil penelitian yang dibandingkan dengan Standar nasional Indonesia menunjukkan kadar amilosa beras Pandanwangi tergolong dalam kategori sedang untuk kecamatan Cibeber, Campaka, Warungkondang, Cianjur, Gekbrong dan Cugenang. Hasil tersebut merupakan kategori yang berbeda dengan hasil kadar amilosa untuk kecamatan Mande yang tergolong kategori tinggi.

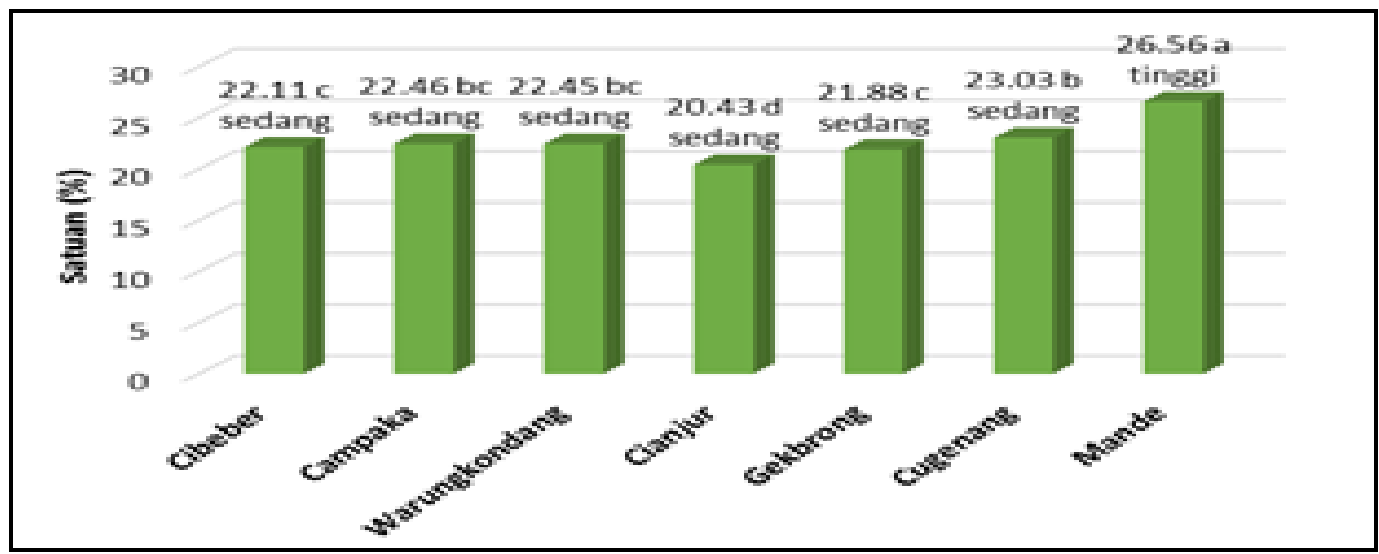

Gambar 1. Histogram hasil analisis amilosa beras Pandanwangi yang di tanam di tujuh Kecamatan.

Keterangan: Hasil uji Tukey: angka yang diikuti huruf yang sama artinya tidak berbeda nyata, sedangkan angka yang diikuti huruf yang berbeda artinya berbeda nyata pada taraf $\alpha 5 \%$.

Hasil analisis sidik ragam percobaan menunjukkan ada pengaruh lokasi tanam terhadap kadar amilosa beras Pandanwangi. Hasil menunjukan bahwa kadar amilosa tertinggi yaitu dari kecamatan Mande bernilai rata-rata sebesar 26,56\%, dimana nilai tersebut menunjukan beras beramilosa tinggi yakni $>25 \%$. Sedangkan, beras Pandanwangi dari Kecamatan Cianjur memiliki kadar 
amilosa terendah yaitu bernilai rata-rata 20,43\%, nilai tersebut menunjukan beras beramilosa sedang yakni 20-25\%. Menurut Aryunis (2010), kandungan amilosa beras akan mempengaruhi mutu tanaknya, terutama tingkat kepulenan/tekstur nasi yang dihasilkan. Anhar (2011) dalam penelitiannya menyatakan beras yang mengandung amilosa rendah nasinya akan lengket. Sebaliknya, beras yang amilosanya tinggi nasinya akan menjadi pera dan tidak lengket. Tinggi rendahnya kadar amilosa dalam beras dapat dipengaruhi oleh interaksi antara tanaman padi dengan lingkungannya, hal ini didukung oleh hasil penelitian Anhar et al (2007) yang menyatakan bahwa lokasi tanam akan berpengaruh terhadap kadar amilosa padi sawah. Sejalan dengan Masniawati et al (2013) yang menyatakan bahwa beragamnya kandungan amilosa kemungkinan dipengaruhi oleh genetik, zona pertumbuhan dan lingkungan.

Dilihat dari lokasi tanam, Kecamatan Cianjur memiliki ketinggian tempat $500 \mathrm{~m}$ dpl sedangkan Kecamatan Mande ketinggian tempat $336 \mathrm{~m} \mathrm{dpl}$, perbedaan ketinggian tempat akan menjadi faktor yang mempengaruh adanya perbedaan interaksi antara tanaman dengan lingkungannya, serta faktor lain seperti sistem berbeda saat budidaya padi Pandanwangi, akan menghasilkan kadar amilosa yang berbeda tiap lokasi kecamatan, hasil ini sejalan dengan penelitian Waryat dan Handayani (2017), bahwa beras yang dihasilkan dengan sistem budidaya organik memiliki kandungan amilosa lebih rendah dari beras dengan sistem budidaya anorganik.

Dari ke tujuh kecamatan yang ditanami padi Pandanwangi, enam beras Pandanwangi memiliki kadar amilosa yang sesuai dengan karakteristik tekstur beras Pandanwangi yaitu pulen, sedangkan satu beras yang berasal dari Kecamatan Mande memiliki kadar amilosa tinggi diatas 25\% yang akan menghasilkan nasi cenderung pera. Menurut Standar Nasional Indonesia 6128 tahun 2015 tentang beras, menyebutkan bahwa penentuan tekstur pera/pulen salah satunya dari kadar amilosa. Kriteria tekstur nasi pera kadar amilosanya $>25 \%$, tekstur nasi pulen kadar amilosanya 20-25\%, tekstur nasi sangat pulen kadar amilosanya 15-20 persen dan nasi dengan tekstur lengket kadar amilosanya $<15 \%$.

Dalam penetapan kadar amilosa beras Pandanwangi di tujuh lokasi kecamatan, menunjukkan jika perlakuan Kecamatan Mande sebesar 26,56\% secara statistik berbeda nyata dengan ke enam perlakuan lainya. Karena topografi yang tidak sesuai dengan kriteria padi Pandanwangi pada proses penyerapan nutrisi yang menentukan kadar amilosa beras. Sistem budidaya anorganik menentukan kadar amilosa beras, karena pupuk yang digunakan. Pemberian pupuk organik akan meningkatkan kadar protein beras dan menurunkan kadar amilosanya (Setyono et al., 2006).

Kecamatan Cibeber, Campaka, Warungkondang dan Gekbrong secara statistik tidak berbeda nyata, karena dalam waktu panen, teknik budidaya dan ketinggian tempat. Keempat kecamatan tersebut sama-sama berada diketinggian tempat sesuai yaitu 650-590 m dpl, dipanen pada minggu yang sama dalam bulan dan tahun yang sama dan menggunakan teknik budidaya organik dan semi organik, Ketinggian tempat berpengaruh terhadap suhu lingkungan, suhu dapat mempengaruhi kandungan amilosa. Hal ini sejalan dengan penelitian Juliano (1979), menunjukkan bahwa beras dengan varietas yang sama namun ditanam pada daerah yang memiliki perbedaan perbedaan suhu udara lokasi penanaman yang berbeda menghasilkan beras dengan kandungan amilosa yang berbeda, begitu juga sebaliknya. Selain itu, keempat lokasi Kecamatan tersebut menggunakan pupuk organik dalam budidayanya yang dapat menambah unsur $\mathrm{N}$ dalam tanah, yang mempengaruhi kandungan amilosa. Hal ini sesuai dengan penelitian Argasasmita (2008), bahwa kadar amilosa beras dipengaruhi oleh varietas, suhu udara lokasi penanaman dan kadar $\mathrm{N}$ dalam tanah.

Berbeda dengan faktor yang menyebabkan perlakuan kecamatan 
Cianjur secara statistik berbeda nyata dengan Kecamatan Cugenang. Diduga karena beras yang diteliti dari Kecamatan Cugenang merupakan hasil budidaya di Desa Sarampad yang merupakan desa diluar dari desa areal tanam padi Pandanwangi yang sudah terindikasi geografis dalam buku Indikasi Geografis Beras Pandanwangi tahun 2015, meskipun masih dalam wilayah Kecamatan Cugenang. Selain itu dalam teknik budidaya dan irigasi serta ketinggian lokasi penanaman, perlakuan Kecamatan Cugenang dilakukan dengan budidaya semi organik, teknik irigasi tersier dan lokasi penanaman lebih tinggi dari lokasi tanam Kecamatan Cianjur. Sedangkan perlakuan Kecamatan Cianjur melakukan budidaya organik dan irigasi semi teknis. Lingkungan dapat mempengaruhi kandungan dari hasil produksi. Hal itu diperkuat oleh Ismail et al., (2003) yang mengungkapkan bahwa suatu varietas yang memiliki satu gen yang sama akan menghasilkan fenotip sesuai dengan kondisi yang dipengaruhi oleh lingkungan.

Setiap beras pasti memiliki kadar amilosa yang berbeda karena perbedaan suhu setiap lokasi Kecamatan. Peningkatan atau penurunan suhu berpengaruh pada ketinggian tempat dan kelembaban lokasi yang dapat mempengaruhi kandungan beras setiap lokasi. Selain itu, perbedaan kadar amilosa beras diduga dipengaruhi oleh lama penyimpanan. Beras akan mengalami perubahan selama penyimpanan dapat mempengaruhi kandungan amilosa dalam beras, karena menurut Pangerang dan Rusyati (2018) menyatakan bahwa kadar amilosa akan meningkat selama penyimpanan, disebabkan suhu dan lamanya penyimpanan.

\section{KESIMPULAN}

Lokasi tanam yang berbeda dari tujuh Kecamatan, yaitu Kecamatan Cibeber, Kecamatan Campaka, Kecamatan Warungkondang, Kecamatan Cianjur, Kecamatan Gekbrong, Kecamatan Cugenang dan Kecamatan
Mande berpengaruh terhadap kadar amilosa beras Pandanwangi. Dari ketujuh lokasi tanam yang berbeda menghasilkan kadar amilosa pada taraf sedang sesuai dengan karakteristik beras Pandanwangi, kecuali kecamatan Mande dengan kadar amilosa tinggi.

\section{DAFTAR PUSTAKA}

Anhar, A., Sudirman., Leilani dan Yenti. 2007. Kandungan Amilosa Beras Beberapa Varietas Padi Sawah yang Ditanam di Sentra Produksi Padi Sawah di Sumatera Barat. Makalah SEMIRATA-BKS Barat. Universitas Islam Negeri. Jakarta.

Anhar, A. 2011. Stabilitasi Kandungan Amilosa Beras Beberapa Varietas Padi Sawah di Sumatera Barat. Jurnal Saintek. Universitas Negeri Padang. Padang. 3 (1): 13-21.

Argasasmita, T.U. 2008. Karakterisasi Sifat Fisikokimia dan Indeks Glikemik Varietas Beras Beramilosa Rendah dan Tinggi. Skripsi. Institut Pertanian Bogor. Bogor.

Aryunis. 2010. Karakterisasi dan Identifikasi Mutu Beras dari Padi Ladang Lokal Asal Kabupaten Tanjung Jabung Barat. Jurnal. Universitas Jambi. Jambi. 1 (4): 1627.

Asih, H.G. dan Syamsiah, M. 2019. Aplikasi Gliocompost untuk Meningkatkan Pertumbuhan Bibit Padi Pandanwangi (Oryza sativa L.var.aromatic). Jurnal Agroscience. Fakultas Sains Terapan Universitas Suryakancana. Cianjur. 9(1) : 13-25

Boediono, Mario. P.A. 2012. Pemisahan dan Pencirian Amilosa dan Amilopektin dari Pati Jagung dan Pati Kentang pada Berbagai Suhu. Skripsi. Institut Pertanian Bogor. Bogor.

BSN (Badan Standarisasi Nasional). 2015. Standar Nasional Indonesia 6128:2015. Beras. Badan Standarisasi Nasional. Jakarta.

Ismail, B.P., Suprihatno, H Pane and I. Las. 2003. Pemanfaatan penciri 
abiotic lingkungan tumbuh dalam seleksi simultan galur padi gogorancah toleran kekeringan. Pusat Penelitian dan Pengembangan Tanaman Pangan Bogor dalam Makarim, A. K, and Ikhwani, Respon Komponen Hasil Varietas Padi Terhadap Perlakuan Agronomi. Jurnal Penelitian Pertanian Tanaman. 27 (1): 33-34.

Juliano, B.O. 1979. Amylose Analysis in Rice. IRRI. Los Banos.

Lestari, R., Kartini, S., Berti, L., dan Romita, M. 2018. Penetapan Kadar Amilosa dan Protein Pada Beras Solok Jenis Anak Daro dan Sokan Yang Ditanam dengan Sistem Pertanian Organik dan Sistem Pertanian Konvensional. Jurnal. Universitas Abdurrab. Pekanbaru. 1 (2) : 28-32

Luna, P., Herawati, H., Widowati, S., dan Prianto, A.B. 2015. Pengaruh Kandungan Amilosa terhadap Karakteristik Fisik dan Organoleptik Nasi Instan. Jurnal Penelitian Pascapanen Pertanian. Balai Besar Penelitian dan Pengembangan Pascapanen Pertanian. Bogor. 12(1) : 1 - 10

Masniawati, A., E. Johannes., A.I. Latunra dan N. Paelongan. 2012. Karakterisasi Sifat Fisikokimia Beras Merah pada beberapa Sentra Produksi Beras di Sulawesi Selatan. Jurnal. Universitas Hasanuddin. 2 (2). 13-24.

MP3C (Masyarakat Pelestari Padi Pandanwangi Cianjur). 2015. Buku Persyaratan Permohonan Pendaftaran Indikasi Geografis Beras pandanwangi Cianjur. MP3C. Cianjur.

Pangerang, F dan N. Rusyanti. 2018. Karakteritik dan Mutu Beras Lokal Kabupaten Bulungan Kalimantan Utara. Jurnal. Universitas Kalimantan Utara. 1 (20): 32-43.
Setyono, A.A., Guswara., Noor dan Handoko. 2006. Evaluasi Kadar Protein Beras Giling Hasil Panen dari Berbagai Dosis Aplikasi Urea. Jurnal. Balai Besar Penelitian Tanaman Padi. Subang. 41 (2): 1932.

Waryat dan Handayani. 2017. Karakteristik Mutu Beras Organik dan Non Organik. Jurnal. Balai Pengkajian Teknologi Pertanian Jakarta. Jakarta. 5 (1): 24-37. 